\title{
The Goa-Ceylon Religious Connection: A Review of the 'The Indian Cry' of Alvares Mar Julius, Archbishop of Ceylon, Goa and India
}

\section{Pratima P. Kamat}

Goa University. India.

\begin{abstract}
Goa, a former Portuguese colony and, at present, a state of the Republic of India, located on the west coast of the subcontinent, has an interesting history of commercial and cultural contacts with Ceylon that were nurtured through the maritime route, especially during the colonial period.
\end{abstract}

Portuguese Goa enjoyed thriving trade relations with the Ilha de Ceilão. It also participated in the Christianisation of this island both under the Portuguese and later, in the seventeenth century, when the Goan priest, Fr. Joseph Vaz, and other Oratorians, made a bid to revive Roman Catholicism there. In 1885, Msgr. Sebastião Rodolfo Dalgado was deputed to Ceylon as its Vicar-General. He served there for two years and with the surrender of their mission of Ceylon by the Portuguese, he returned to Goa in 1887. And in the very same year, 1887, another Goan priest, Padre Alvares, journeyed to Ceylon to contribute to its religious history: initially, to rally the Goan clergy posted there in their fight against the Concordat of 1886, and later to perform his episcopal duties as the Archbishop of Ceylon, Goa and India.

Alvares Mar Julius, also known as Padre Alvares, was an editor, writer, founder of educational and social institutions, patriot and, above all, a dedicated social worker. In the pursuit of the spiritual and socio-political uplift of his people, Padre Alvares was branded seditious by the colonial Government of Goa, ex-communicated by the Roman Catholic Church, and elevated to episcopal stature by the Syrian Orthodox Church in the last quarter of the nineteenth century.

The present article focuses on the socio-political contributions of Alvares Mar Julius both before he joined the Syrian Orthodox Church and after. It examines the ideology of economic nationalism espoused by Padre Alvares, the "swadeshi" (nationalist) ideology, and attempts to situate this revolutionary priest in the context of local resistance to colonial hegemony in nineteenth century Goa. Further, it reviews the contributions of Alvares Mar Julius to the Syrian Orthodox Church which have been many-fold, with a special focus on his activities in Ceylon in the context of The Padroado Defence Association, the Independent Catholic Mission, and as his mission-field.

"I have fought the Good Fight

I have finished the race

I have kept the faith."

--- 2 Timothy 4:7-8 


\section{Introduction}

A couple of years ago, the High Commissioner of Sri Lanka in India, Prasad Kariyawasam, had said: "Portuguese had their first introduction to Sri Lanka in Galle, a southern port city in 1505 and 'Goa, God's own paradise' and 'Sri Lanka, a land like no other' have common threads."2 Indeed, Goa, a former Portuguese colony and, at present, a state of the Indian Union located on its west coast, has an interesting history of commercial and cultural contacts with Ceylon that were nurtured through the maritime route, especially during the colonial period. While Sri Lanka, like Goa, was a trading post for Arabian, Persian, Greek and Chinese traders in the ancient and early medieval times, "Goa and Galle saw their paths meet with the conquest by the Portuguese."3

Sri Lanka had experienced the rule of three successive European powers from 1505 to 1948: the Portuguese (1505-1658), the Dutch (1658-1796) and the British (1796-1948). The "rule" of these three European powers was sometimes "nothing more than a presence that grew, spread, or declined in space and time" (EWC, 2006: 23). During the period of the Portuguese presence, from 1505 to 1658, Goa's contacts with Ceylon, particularly, Colombo, Galle and Jaffna, expanded.

The islands of Goa had been captured by the Portuguese in 1510. According to some, Ceylon, "This loveliest parcel of land the Creator has placed in this Earth,"4 (Pieris, 1920) should have served as "the centrepiece of Portugal's political, military and colonial policy in Asia" and been made its headquarters (Zupanov, 2006). However, it was Goa that was accorded the status of the capital of the Estado da Índia (the Portuguese State of India) in 1530. And since, the contacts between the two lands increased manifold. Trade, especially in spices, cinnamon in particular, flourished and Portuguese Goa enjoyed thriving commercial relations with the Ilha de Ceilão. Ceylon was also used to deport the condemned and the exiles found guilty by the High Court at Goa and the Goa Inquisition. The convicts were generally sent to war-torn regions where there was an acute need of manpower, and in the early seventeenth century, in the wake of internal wars and the Dutch incursions, the rate of deportation from Goa to Ceylon increased considerably (de Souza, 2010).

\section{The Goa-Ceylon Religious Connect}

Goa had also participated in the Christianisation of this island under the Portuguese. It had thus contributed to the "temporal and spiritual conquest of Ceylon' 5 by the Portuguese in the sixteenth and the first half of the seventeenth centuries. In 1658, the Dutch commercial company, the Verenigde OostIndische Compagnie (VOC, or Dutch United East India Company), which had entered the Sri Lankan scene at the beginning of the seventeenth century, succeeded in upstaging the Portuguese from the island. In his book, The 
Temporal and Spiritual Conquest of Ceylon, written in 1688 and published in 1916, Queiroz, had given a call to "go back and reclaim this land for Portugal and for God" (Zupanov, 2006).

Under the Calvinist Dutch, the Roman Catholic converts of Ceylon had suffered considerably and hence there were some, like Queiroz, who made repeated appeals for the Portuguese recon quest of Ceylon with a view to alleviate the plight of the local Catholics (Zupanov, 2006). While an irreversible decline had already set in the Estado da Índia rendering the temporal recovery of Ceylon to nought, its spiritual recon quest was still considered with favour by some missionaries. In the seventeenth century, a Goan priest, Fr. Joseph Vaz, and the Congregação do Oratório de Santa Cruz dos Milagres (Congregation of the Oratory of the Cross of Miracles), also known as the Oratorians, Milagristas, Padres Bragmanes, etc., converted this island into their missionfield in a bid to revive Roman Catholicism there. The Oratorian Sri Lankan mission contributed in no mean mite to the continuance of the Roman Catholic religion and the jurisdiction of the Padroado Real on this island.

Padroado Real, or the Crown Patronage of the Church, which exemplified the "the indissoluble union of the Cross and the Crown" (Boxer, 1969) was a set of privileges granted by the Holy See to the King of Portugal to spread Christianity and to name the personnel for this purpose, in all the lands in the East "discovered or yet to be discovered (repertis et reperiendis)" by them. The Padroado "was one of the most jealously guarded and tenaciously maintained prerogatives of the Portuguese Crown" (Boxer, 1969) and could not be revoked by the Vatican without the prior consent of the monarch of Portugal. The Padroado was abolished in Ceylon and these dioceses were placed under the Propaganda Fide with the signing of the Concordat between the Holy See and Portugal in 1886 and the subsequent Papal Bull, Humanae salutatis auctor of 1 September 1886, (Abba Seraphim, 2006).6 With the renunciation of its claims in Ceylon by Portugal, Goa's religious jurisdiction in that territory ceased.

The Padroado Real had provided Goans an opportunity to serve in Ceylon. Amongst them was the eminent Msgr. Sebastião Rodolfo Dalgado who was deputed to Ceylon as Vicar-General in 1885. He served there for two years and with the surrender of their mission of Ceylon by the Portuguese, he returned to Goa in 1887. And in the very same year, 1887, yet another Goan priest, Padre Alvares, journeyed to Colombo to contribute to the religious history of Sri Lanka: initially, to rally the Goan clergy posted there in their fight against the Concordat of 1886, and later to perform his episcopal duties as the Metropolitan of Ceylon, Goa and India, excluding Malabar.

Bishop Alvares, known as Padre A.F.X. Alvares in Goa, was an editor, writer, founder of educational and social institutions, patriot and, above all, a dedicated 
social worker to whom the church was "the community of Faith, hope and charity,"7 and who aspired to make the civil and ecclesiastical administration of Portuguese Goa likewise. This firebrand journalist and fearless patriot used his pen and raised his voice to fight against the corruption and malpractices in the contemporary colonial administration of Goa. In the pursuit of the spiritual and socio-political uplift of the people, Alvares was branded seditious by the colonial government of Goa and forced to leave the Roman Catholic Church. He joined the Syrian Orthodox Church which consecrated him archbishop of Ceylon, Goa and India (excluding Malabar) with the title of Mar Julius.

The present article focuses on the socio-political contributions of Alvares Mar Julius within the framework of his "swadeshi" (nationalist) ideology, both before he joined the Syrian Orthodox Church and after. He embraced the Syrian Orthodox Church believing it to be more Indian and Asian in its activities. And his commitment to economic nationalism made Padre Alvares a strong advocate of the consumption of local goods and development of agro-based industries, a first step towards economic self-reliance and eventual liberation of his homeland, Goa, from colonial yoke. Hence, an attempt has been made to situate this revolutionary priest in the context of local resistance to colonial hegemony in nineteenth century Goa.

\section{Portuguese Goa: Local Resistance}

Portugal was the first European country to establish its colonial presence in India and the last to leave its shores with Goa serving as the headquarters of its Estado da Índia for several centuries. Goa remained under the Portuguese rule from 1510 to 1961 , although with varying territorial boundaries. 8 Right from the sixteenth century, when the Portuguese conquered the islands of Goa, to the twentieth century, which witnessed the territory's struggle for freedom, the history of Goa has been studded with revolts and other examples of local resistance to colonial hegemony.

In the early centuries of their rule in Goa, the Portuguese pursued a policy of religious persecution and racial discrimination which generated an oppositional discourse that included, within its repertoire, acts and attitudes of resistance, manifested through conventional conscious confrontation and in the form of everyday as well as creative resistance as also resistance of collaboration (Kamat, 1999 and 1989).

The second decade of the nineteenth century witnessed the stormy introduction of constitutionalism in Portugal. Under the Portuguese constitutional monarchy (1820-1910) a limited right of franchise was granted to the Goans. During this period, Goans like Bernardo Peres da Silva, Jeremias Mascarenhas, José Inacio de Loyola, Francisco Luís Gomes and Padre Alvares often resorted to campaigns in the press and public protests in defense of their newly acquired 
political rights9 (Kamat, 1999). Further, during this period, as the Estado da India consolidated its gains in the territories of the 'New Conquests' of Goa and proceeded on a neo-imperialistic spree in Africa, new areas of conflict emerged from within - the revolts of the Ranes and mutinies of the sipais (Indian soldiers) (Kamat, 1999 and Kamat, 1999).

The ideologies of brahmanism 10 (that sought to critique the corrupt and exploitative policies of the colonial regime) and Indianness (that strove to emphasize Goa's Indian connection and argued for the creation of an economically self-sufficient, socio-culturally united and politically aware Goa) dominated the nineteenth century political scene in Goa and it is within this context, that the speeches, writings and activities of Padre Alvares may be analyzed.

\section{Early Years}

António Francisco Xavier Alvares was born in Verna, in the Salcete taluka11 in South Goa, on 29 April 1836. The Alvares family was locally hailed as "devanghar" (house of God) in acknowledgement of the many acts of charity performed by its members. True to the principles of his family, Padre Alvares championed the cause of the downtrodden, seeking to protect them against the oppressive rule of the colonial administrators.

After completing his education at the Rachol Seminary in 1859, Alvares proceeded to Bombay where he was ordained priest by the Bombay Vicar Apostolic, Bishop Walter Estein, S.J., albeit without any demissorials from the archbishop of Goa (Vaz and Costa Campos, 1925). Here, he served as an assistant priest at Bandra and in 1865 proceeded to Belgaum in a similar posting (Humbert, 1964). Upon his return to Goa in 1867, for the next couple of decades, Padre Alvares exercised his sacerdotal functions as an apostle of charity, an educator, a firebrand journalist and later as a political activist.

\section{Apostle of Charity}

Padre Alvares had started Associations of Charity in Panaji, at Verna and elsewhere in Goa which gave alms to the poor, free medical assistance to the sick and the infirm and decent burials to solitary souls. He was also a founder of educational institutions. A dedicated social worker, Alvares launched preventive campaigns against epidemics like cholera, small pox and the bubonic plague and worked hard for the recovery of the afflicted. In 1883, he published a booklet, Directions for Treatment of Cholera, to educate the public about this "formidable enemy of the human race" (Alvares, 1883). He was particularly well known for the social service that he rendered to the bhangi (scavenger) community of Fontainhas, Panjim. 


\section{Firebrand Journalist}

His strong patriotism and journalistic acumen led Padre Alvares to be associated with the publication of several newspapers through the medium of which he put his views before the public. These included A Cruz (The Cross), A Verdade (The Truth), O Progresso de Goa (The Progress of Goa), The Times of Goa and $O$ Brado Indiano (The Indian Cry). The titles of these newspapers are by themselves a clear indication of the nature of his activities. It is quite explicit that he was interested in "the truth" and in "the progress of Goa" and that he was very much concerned about the (anguished) cry of the Portuguese Indians (Goans).

On 27 August 1886, Alvares delivered a talk on the situation prevailing in Goa (Azevedo, 1988). His social, religious and economic criticism of the corrupt civil as well ecclesiastical administration and the superficial, luxury-oriented colonial society eventually led to Padre Alvares being accused of sedition.

\section{The 'Swadeshi' Ideology of Padre Alvares}

Padre Alvares was a strong advocate of the use of Goan commodities in place of their foreign substitutes. His newspaper, which was significantly named $O$ Brado Indiano, or The Indian Cry, contained a section in which the advantages of the "national customs" in clothes, food habits, houses, and the like, were loudly lauded and the people were asked to give up the fashions and products of Portugal in favor of the former (Gomes da Costa, 1939). Padre Alvares had also formed an 'Association against Luxury' to fight the use of luxurious items from abroad and encourage their local substitutes instead. Thus, years before Lokmanya Tilak and other Indian nationalists had advocated the consumption of swadeshi or local goods, and the boycott of foreign products, Padre Alvares had initiated a similar plea in Goa. So absolute was his 'swadeshi' (nationalist) spirit that he implored Goans "to emigrate to any territory where everything was Indian" (Gomes da Costa, 1939).

In order to increase the income of his motherland and make it as self-sufficient as possible, Padre Alvares advocated the optimum utilization of its natural resources. He also spoke of the introduction of new, high-yielding crops in Goa and at the same time called upon the people to expand and diversify the existing home-based industries.

Padre Alvares made a special appeal to the Goan youth to renounce merrymaking and instead take up the laborious, yet rewarding cultivation of the crop, mandioca, which would improve the finances and the food-stocks of their motherland. Alvares felt that "This would channelize the superficial pleasures of dancing and feasting into the true joys of work, sweat and sacrifice" (Álvares, 1916). Mar Dionysius, Metropolitan of Malabar, had 
written to Alvares Mar Julius about his willingness to help with the promotion of mandioca (Álvares, 1916).

Citing the example of Trichinopoly, a city in southern India, whose prosperous economy had been built on its arecanut and banana plantations, this 'swadeshi'minded prelate censured his fellow countrymen for ignoring the lucrative commercial potential of the local coconut and mango plantations. He also highlighted the vast mineral potential of Goa and urged Goans to use this raw material, not for earning a fast buck by exporting it, but to industrialize Goa. In his writings, he made frequent appeals to his fellow country people to shed off their lethargy and unveil the hidden economic wealth of their land and thereby liberate themselves from the clutches of poverty (Álvares, 1886).

He was equally critical of the colonial administration of the day that dealt with the local people in an unjust, harsh and, at times, racist manner. Through his newspaper, $O$ Brado Indiano, Padre Alvares conducted a determined campaign against the corrupt and negligent officials. This, in turn, led to charge of sedition being leveled against him.

\section{Seditious?}

The year 1895 was a tumultuous year in the history of Goa, for its second half witnessed three events of immense political significance, one following the other, within the space of three months: the 'Sedition' of Padre Alvares in August, the Maratha Sipai Mutiny in September and the Dada Rane Revolt in October. All the three were said to be woven together with the nativistic spirit of 'India for the Indians.' The accusation of sedition was made by the Administrator of Ilhas, Captain Manuel d'Oliveira Gomes da Costa, to condemn Padre Alvares, who had initiated a press campaign against him.

Right from its first issue, $O$ Brado Indiano vocalized the needs of the downtrodden and criticized the bureaucrats for siphoning a large portion of the income of the state for their personal use, while the sons of the soil were compelled to emigrate in search of a decent livelihood (Luso Goense, 1896).

The Portuguese officers who were sent out to Goa were little better than clerks and sergeants who adhered to the dictum, "I want, I can and I order" ("quero, posso e mando") (O Brado Indiano, 12 October 1895). What they lacked in superior intellect, they displayed in terms of unchecked tyranny and racism. One of the autocratic and corrupt officials targeted by O Brado Indiano was the administrator of Ilhas, Manuel d'Oliveira Gomes da Costa who, in the discharge of his official duties, was extremely high-handed and cruel, ruling with a big stick ("bambu de quatro varas") (A India Portugueza, 1895). He also meted out harsh treatment to the press, in particular to those newspapers that dared to criticize his administration. Since he was in charge of the police 
force of the capital city, Panjim, Gomes da Costa often illegally levied fines and ordered arbitrary imprisonment of his critics and rivals.

In addition to this, the color-bar that was rife in military and civil appointments, penetrated into the social field as well. The Nova Goa Club of Panjim, which had previously kept its doors open to all, now restricted its membership to Europeans alone (Sertório Coelho, 1895 ; Bruto da Costa, 1920).12 It was, thus, "Europeanism," with its exploitative and arbitrary nature, that had generated critical pieces of journalism in the local press, most notably in $O$ Brado Indiano. Deliverance from such a miserable state of affairs was the crying need of the hour.

In its issue dated 27 July 1895, O Brado Indiano had carried an article entitled "Enigma para Adivinhação" ("A Riddle to be Solved") which invited its readers to identify the corrupt officer described by it. Gomes da Costa promptly accused the newspaper of slander (O Brado Indiano, 1895)13 and set himself on the trail of the "native sedition" ("sedição nativista") with Padre Alvares as his principal target.

Three weeks later, on 19 August 1895, Padre Alvares was charged with "inciting the people to fight for liberation," "discrediting the Portuguese," and insulting government officials (Correio da India, 1895; O Brado Indiano, 1895). He was arbitrarily arrested and locked up in a filthy, ill-lit and poorly ventilated cell - "a modern Bastille" (O Ultramar, 1895) - for the night. Padre Alvares was presented before the Judge who censured the police for failing to adopt the correct procedure, and after questioning the accused, released him (Vinte e um de Setembro, 1895).

However, the following evening, Alvares was arrested again, this time for violating those sections of the Portuguese Penal Code which sought to punish Catholics who either publicly denounced or showed disrespect to the Roman Catholic religion or wore the robes or ensigns of other religions when they were not entitled to do so (Correio da India, 1895).14 Although Alvares did not fall under any of these categories, the charges were pressed upon him because the Roman Catholic Church of Goa had refused to accept his Syrian connections. To them, he was a rebellious priest whose ordination had been cancelled. Despite a previous acquittal in 1890, when the court had permitted him to use his Syrian episcopal dress (Vinte e um de Setembro, 1895),15 Alvares Mar Julius was tried for the same 'crime' twice. The next day, he was subjected to the humiliation of being stripped of his episcopal habit and ensigns and taken to the lock-up in his underclothes. In the court an attempt was made to revive the charges of sedition and high treason. The case was dismissed for want of evidence. In his ruling, the judge stated that although sedition was said to be in the air, he had not smelt it, most probably because he was suffering from chronic coryza! (Correio da India, , 1895; O Brado Indiano, 1895). 
The residents of Panjim extended support to Padre Alvares by accompanying him to and from the prison in large numbers. The people of Ilhas protested to the governor-general against the abuses of power by the administrator (Sertório Coelho, 1895). Similarly, Goans residing in Bombay had represented to the king of Portugal against the same officer (Sertório Coelho, 1895). Thanks to his Syrian connections, local people in Ceylon and Udupi, some 3000 of them, had publicly demonstrated against the humiliation heaped on Bishop Alvares (O Brado Indiano, 1895).

From the preceding paragraphs it is clear that Padre Alvares was primarily a social reformer and an economic thinker who sought to make the Church a veritable mother of the people, the economy more diversified and productive and the administration more in tune with the needs of the general public. Although he was charged with sedition, Alvares' protests were more against the malpractices present in the administration of Goa than against the foreign rule as such.

In the nineteenth century there was no question of broadening this spirit of 'swadeshi' to mean a merger of Goa with India, nor was an independent existence for Goa possible because of its economic dependence on others, military weakness and the covetousness with which Britain regarded it. Hence, the 'swadeshi' ideology of Padre Alvares was basically aimed at generating employment, improving the agricultural and industrial production locally and consequently bringing about an increase in the income of his compatriots and the revenue of his homeland. After the 'sedition' controversy, Bishop Alvares proceeded to his Brahmavar Mission where he remained till 1912 when he returned to the land of his birth.

\section{Antioch and Rome: The Universal Supremacy of the Church of Christ}

His pride in Asia and the Asians had made Padre Alvares denounce the claim of the Pope as the head of all Christians in favor of the Patriarch of Antioch who was considered the rightful head of the Church since God's revelation had taken place in Asia. In his book, A Supermacia Universal na Egreja do Christo, provada pela Escriptura, Tradição e Escriptores insuspeitos a Egreja Romana (The Universal Supremacy of the Church of Christ as proved by the Scriptures, Tradition and the Writers of Scriptures not suspicious of the Roman Church), published in Colombo in 1893, along with its English version, Antioch and Rome, Alvares presented "a spirited plea on behalf of the Apostolic See of Antioch as against the claims of Rome."

One reason for leaving the Roman Catholic Church was his quarrel with the archbishop of Goa, D. António Sebastião Valente, who had banned the newspaper, A Cruz (The Cross), edited by Alvares, on 26 July 1882, for being "systematically hostile to the ecclesiastical authorities, defamatory, scandalous, revolutionary, and a disturber of the peace of conscience." 


\section{In Ceylon to rally support against the Concordat}

Harassed by Archbishop Valente, who was officiating as Governor of Goa for a few months in 1885-1886, and attacked on both the ecclesiastical and civil fronts, in 1887, Padre Alvares finally left the Church in which he had been ordained and joined the Syrian Orthodox Church. From Goa, Alvares went to Ceylon where he came in contact with the Apostolic Suryani Church of Antioch and the "Swathantra Catholic Mission"16 (Independent Catholic Mission) which was opposing the Concordat of 1886 whereby the Padroado churches of Ceylon were placed under the control of the Propaganda Fide.

With the territorial and political decline of the Portuguese empire in the East, attempts were made to abolish the Padroado Real. The takeover by the Sacred Congregation for the Propagation of the Faith (Propaganda Fide) of the administration and care of the Padroado missions had led to a conflict over the rights of jurisdiction (referred to as the Goan or Indo-Portuguese schism) between the Goan clergy of the Padroado and the Vicars-Apostolic functioning under the Propaganda Fide.

Attempts were made to resolve this conflict and finally, on 23 June 1886, a Concordat was signed between the Holy See and the Government of Portugal whereby the Padroado was abolished in Ceylon and later, by the Papal Bull, Humanae salutatis auctor of 1 September 1886, these dioceses were placed under the control of the Propaganda Fide (Abba Seraphim, 2006: chapter 3). With the renunciation of its claims in Ceylon by Portugal, Goa's jurisdiction in that territory ceased.

The Concordat was opposed by Goan clerics and expats in Ceylon. In Goa, a meeting was held on 21 October 1886, to protest against the Concordat at which Alvares presented a "passionate defence of the rights of Padroado against the onslaughts of Propaganda" (Azevedo, 1988; Alvares, 1886). Padre Alvares along with persons like Dr. Lisboa Pinto of Ceylon had constituted The Padroado Defence Association (Seraphim, 2006) with headquarters in Goa and branches in different towns of Ceylon. In February 1887 Padre Alvares proceeded to Ceylon to rally the Goan clergy posted there in their fight against the Concordat. Some of the former Padroado churches of Colombo had broken free of the Holy See and had constituted themselves as the Independent Catholic Mission (Seraphim, 2006). They approached Mar Dionysius V, the Syrian Orthodox Metropolitan of Malabar, for a transfer of spiritual jurisdiction.

Padre Alvares contacted the Malankara Metropolitan, Mar Joseph Dionysius, who directed him to Mar Gregorios of Parumala, later glorified as St. Gregory of Parumala, who received Alvares into this Church and elevated him to the monastic rank of ramban. On 15 August 1888, Mar Dionysius appointed Alvares as Apostolic Prefect of the former Padroado churches in Ceylon, 
authorizing him "to officiate on our behalf amongst our children who are now straying like a flock without a shepherd" (Seraphim, 2006). Consequently, on 4 November 1888, the archbishop of Colombo issued a decree declaring that Alvares had incurred excommunication latce sententice (Seraphim, 2006).

\section{Brahmavar Mission}

Alvares left Colombo for Tuticorin on 15 December 1888. He founded the Brahmavar Mission near Udupi in Karnataka with the aim of providing spiritual leadership to those people who had embraced the Syrian Orthodox Church from the surrounding regions and to enable them to learn liturgy and catechism of the Church.

In the second half of the nineteenth century, Brahmavar's Roman Catholic St. Milagres church, founded in 1678, was placed under the Propaganda Fide, much to the consternation of its faithful whose appeal to be returned to the Padroado fold was turned down by Rome. This led to a revolt under Fr. Roque Zeferino de Noronha, 1847-1936, who had been received into Orthodoxy with Alvares Mar Julius. In 1889, Alvares organized the discontented believers and built a separate church for them. The Malankara Syrian Worship and Qurbana were started here. Alvares Mar Julius and his associates soon had a congregation of over 5,000 along the west coast of India, from Bombay to Mangalore (Alexander, 2005). Slowly but steadily the missionary work of this Mission spread to people and places which are today included in the Indian states of Maharashtra and Andhra Pradesh, in addition to Karnataka. Alvares was most ably supported by Fr. Noronha who zealously thwarted attempts by the Roman Catholic Church to secure the return of the Brahmavar Orthodox Christians. He penned the biography of Bishop Alvares under the title, The Hidden Treasure, Mor Julius Alvarez (1929) (Varghese, 2010).

\section{Latin Rite}

Although he had embraced the Syrian Orthodox Church, Mar Julius continued to use "the traditional Latin Rite corrected for use in Orthodoxy." (Alexander, 2005). He, however, used the Byzantine style vestments. Today, his church at Brahmavar holds mass in the Konkani language spoken by the people of Goa and by some coastal communities in South Kanara, Karnataka. As a part of the traditional Latin rite, the Brahmavar Orthodox Christians include All Saints Day (November 1) and All Souls Day (November 2) in their ritual calendar.

\section{Alvares Mar Julius}

On 29 July 1889, Ramban Alvares was consecrated Metropolitan to the diocese of Ceylon, Goa and India (excluding Malabar), and given the title of Mar Julius , 17 at the Old Seminary, Kottayam, by Paulos Mar Athanasius, Paulos 
Mar Ivanios and St. Geevarghese Mar Gregorios, Metropolitans of Malabar under the jurisdiction of the Apostolic See of Antioch, and under authority of Patriarch Ignatius Peter III (Alexander, 2005; Kiraz, 1961). He was given spiritual authority "to ordain monks, priests, deacons, etc.; to consecrate the oil of baptism and of the sick, as well as (to consecrate) churches, altars, and tablithos; and to exercise all consecrations and spiritual functions, etc., suitable to the rank of Metropolitan under the jurisdiction of Moran the Patriarch, the high-priest, the head of our faith" (Kiraz, 1963).

\section{The Consecration of Vilatte Mar Timotheos in Ceylon}

Alvares Mar Julius brought Roman Catholics like himself who were dissatisfied with the working of the Roman Catholic Church into the Syrian Orthodox Church, ordained and consecrated priests. One of the priests consecrated by Archbishop Alvares Mar Julius was the controversial Joseph René Vilatte described as "the fountainhead of a major series of valid successions which have been dispersed all over the world, especially in Canada and the United States." (Keizer, 2001).

A sizeable group of people had joined the Syrian Orthodox Church in the United States of America and hence it was decided to appoint an Archbishop for North America. Joseph René Vilatte, a native of Paris, who had approached Alvares Mar Julius, was selected for this challenging mission. Vilatte was a Parisian who had migrated to the U.S.A. and trained as a Roman Catholic priest only to join the Methodist Church thereafter. It is said, "his changes of religious affiliation were numerous and bewildering" (Brandreth, 2006).

Alvares had replied to Vilatte, accepting his request for consecration: "We from the Bottom of our hearts thank God that He has mercifully shown you the way out of the slavery of Rome; and we rejoice to see a large number of Christians making heroic efforts in the same direction as ourselves in the New World." He had expressed his willingness to travel to the U.S.A. for the consecration. However, Vilatte preferred to visit Ceylon, instead. In his second letter to Vilatte, Alvares had expressed his delight to welcome the "worthy minister of God from Wisconsin." (Anson, 1964).

Vilatte was consecrated on 29 May 1892, in Colombo, Ceylon, at Our Lady of Good Death Cathedral by Mar Julius, and others, under authority of a Bull of Mar Ignatius Peter III, Patriarch of the Apostolic See of Antioch and of all the East, and conferred on him the title of "Mar Timotheos, Metropolitan of North America", Archbishop for the Church of the Mother of God in Wisconsin of the Archdiocese in America, with "the power to consecrate churches, chancels, cemeteries and all functions appertaining to Metropolitan rank" (Kiraz, 1962).

This was a prestigious event for the Malankara Church. Dr. Lisboa Pinto accorded a warm reception for the Metropolitans, including Alvares Mar 
Julius, who had arrived in Colombo to consecrate Vilatte and he shared the expenses of the consecration ceremony. A renowned group in the U.S.A. awarded the title "Commander of the Crown of Thorns" to the Metropolitans. The people of Colombo submitted a Mangala Patra to the dignitaries, and on their return, the Metropolitans were given a grand reception by the Syrian Christians in Trivandrum and were presented with Mangala Patra.18

On 30 May 1892, an agreement was drawn up between Alvares and Vilatte (Renivilathi Mor Thimothios), in which the latter "acknowledged the Confession of Faith, the canons and Rules of the Syrian Jacobite Church, and rejected all the doctrines which are declared heretical by said Church" and promised to be "subject and obedient to the Patriarch, and to his successors in the Apostolic See of Antioch." However, in the U.S.A., Mar Timotheos soon separated from the Church that had raised him to episcopal dignity and began consecrating bishops against the canon laws of the Syrian Orthodox Church. "The wandering Bishop" (Keizer, 2001) Vilatte was accused of corruption of Holy Orders, of selling them to the highest bidder. He was also accused of having falsified the document which allegedly contained the blessings of the Patriarch of Antioch for his consecration. Mar Timotheos was excommunicated and his consecration and ordinations were declared illegal. In 1924, Vilatte returned to Paris and in the following year, he abjured to the Apostolic Nuncio, expressing his "most sincere regrets" at having left the Roman Catholic Church (Eglise Gnostique Apostolique and Phillip A. Garver, 2002).

The contrast with Alvares Mar Julius cannot be more glaring! While Vilatte, who had been consecrated Bishop by Mar Julius, abnegated the Syrian Orthodox Church which had realized his episcopal dream, Alvares spent his last years in abject poverty without any financial support from the Malankara Church to which he swore his allegiance till his last breath. Ironically, the Vilatte episode earned for Bishop Alvares the opprobrium of his detractors in Goa who used it to denounce him as a high-handed person who had consecrated Vilatte on his own without any sanction from Antioch!

\section{The humble petition of the Christians of the Independent Catholic Mission of Ceylon}

Controversy had dodged Mar Julius in Ceylon and in other parts of the diocese as well. In 1892, there was a difference of opinion between the archbishop and his congregation over the funds of the Colombo mission, with Dr. Lisboa Pinto taking a stand against Alvares. In 1900 an anonymous petitioner submitted The humble petition of the Christians of the Independent Catholic Mission of Ceylon subject to the spiritual jurisdiction of [His Holiness Ignatius A. Messias, Patriarch of Antioch and the East] in which Archbishop Alvares had come in for criticism. 
Avares' fund-raising activities in Caliampur and Ceylon did not find favor with the faithful who suspected that the funds so collected would be used for sustaining the journalistic endeavors of Mar Julius which were political in nature and "... in no way benefited our Mission." The anonymous petitioner had lamented that Archbishop Alvares was not in constant contact with his congregation and that "there exists some misunderstanding between the Christians and His Grace." Further, he stated that "our Archbishop is too old for active work" and, going by the fact that some of the churches of their Mission had returned to the Roman Catholic fold, cautioned, "If we permit the present state of affairs to continue our Mission will sooner or later fall into the hands of our enemies" (Abba Seraphim, 2006).

It was controversies such as the above as well the one mentioned below which made Bishop Alvares return to Goa in 1912.

\section{The Excommunication of Mar Vattasseril Geevarghese Dionysius VI}

On 8 June 1911, the Patriarch of Antioch "excommunicated, deposed, and derobed" (Poothicote, 1990) the newly appointed Malankara Metropolitan, Mar Dionysius VI. Among other factors, the excommunication had been prompted by the refusal of Mar Dionysius VI to sign a registered deed declaring perfect allegiance to the Patriarch of Antioch. The Patriarch, Mar Abdullah II, claimed complete spiritual and temporal authority over the Church of Malabar as a divine right. This was contested by Mar Dionysius VI and his supporters. The Royal Court of Travancore had ruled in its 1889 judgement that the Patriarch had only spiritual oversight, and no temporal authority. "Ignoring this judgment, the Patriarch continued to exercise temporal authority, and the Malankara Church resisted his move. From 1909 onwards both the Patriarch's attempt towards this end and opposition to it were intensified" (Catholicate History,).

On this occasion, Alvares Mar Julius protested against what he regarded as an abuse of power by his Patriarch. In the past, Alvares had accepted the supremacy of the Patriarch of Antioch over the Pope of Rome for being an Asian. Now, the same 'swadeshi' spirit had prompted him to take up cudgels in support of the Malankara Metropolitan who was challenging the absolute control which the Patriarch of Antioch sought to exercise over the Indian church.

Mar Julius and Mar Ivanios (Metropolitan of Malankara, Kandanad Diocese), jointly penned a letter of open and unstinted support to Mar Dionysius VI [dated $2^{\text {nd }}$ Mithun 1086(1911)] in which they argued why the excommunication was unwarranted and highlighted its procedural lapses. The letter insisted that the "Antiochian throne" enjoyed only spiritual control over the Malankara 
Church. Hence, the Patriarch's insistence on Mar Dionysius VI signing an agreement surrendering material powers to him, lacked validity. In their letter, Mar Ivanios and Mar Julius, systematically demolished the allegations made against Mar Dionysius VI and also pointed out that the procedure, as laid down in the canon, had not been followed. They concluded that the excommunication was "against justice, canon law and royal law" and, therefore, unacceptable. The letter ends with a strong and vociferous vote of trust and support issued to Mar Dionysius VI.19

His courageous stand earned for Alvares the respect of many from within the Syrian Orthodox Church but also the ire of others to whom the supporters of Mar Dionysius VI were "a group of misguided nationalists who could not perceive the idea of a church which transcends national and ethnical limitations." (Poothicote, 1990). Incidentally, the 2 July 1928 verdict of a Trust Fund case filed in this context went in favor of Mar Dionysius VI. The judgement declared his excommunication invalid and permitted him to hold the Seminary and other assets of the Church in his possession.20

The excommunication brought to the fore the demand of some members to make their Church fully autonomous. This group approached the deposed Patriarch, Mar Abdul Messiah, to set aside the excommunication of Mar Dionysius VI, which he did on 17 August 1911, and consecrate a Catholicos for their Church. On 15 September 1912, Mar Ivanios was consecrated as the first Catholicos with the name Mar Baseless Palouse I. The chief celebrant of the consecration ceremony was Patriarch Mar Abdul Messiah himself. All the authorities and privileges enjoyed by the Patriarch in the Church as its head were given to the Catholicos. By the consecration of the Catholicos, the Indian Church asserted and declared its full autonomy and became a full autocephalous Church.21

The Patriarchal group questioned the validity of the Catholicate in law courts and the litigation went on up to the Supreme Court. On 12 September 1958, the constitutional bench of the Supreme Court of India recognized the validity of the Catholicate and unanimously declared that the Patriarch of Antioch did not have any authority over the Malankara church and that the Indian church is completely free under the Catholicos of the East.22

Mar Julius had been entrusted with the order issued by the Patriarch cancelling the excommunication of Geevarghese Mar Dionysius VI, which he failed to make public and hence the effort of Mar Dionysius to effect a rapprochement between the two sections did not bear fruit.23 In the wake of this controversy, Alvares Mar Julius decided to return to Goa for good, with his loyalty to the Syrian Orthodox Church undiminished and his spirit of serving the downtrodden untouched. 


\section{Last Years}

With Portugal becoming a secular republic in 1910, Alvares returned home in the hope that he would no longer be subjected to harassment. In Goa, he chose to serve the poor and the needy, especially the lepers and the bhangi community of Fontainhas, Panjim. In his advanced years, with a flowing white beard, he would move from house to house in a tattered black cassock, with a staff and a bowl, collecting alms for the people he had chosen to minister.

Although his contacts with the Syrian Orthodox Church had diminished he was not forgotten by them. In 1915, Mar Gregorios, the Syrian Orthodox Metropolitan of Niranam, described Alvares Mar Julius as "Our sincere fellow worker" and stated, "He still lives and labors as he has for more than a quarter of a century for the propagation of the true apostolic faith of Antioch, as opposed to the corruptions of Rome."24

On account of his single-minded dedication to truth, his vehement abhorrence of corruption and wastage of public funds, his deep-seated interest in the amelioration of the conditions of the poor and the downtrodden, his consequent intolerance of the oppressive colonial administration, and his fiery speeches and writings, Alvares Mar Julius had faced a number of adversities in public life, be it as a priest or as a journalist. His life had been "a prison formed of many links of pain and very little of pleasure" ("...uma cadeia formada de muitos elos de dor, e mui poucos de prazer!’) (Sertório Coelho, 1895). Even in death he was not allowed to rest in peace.

This great social worker died on 23 September 1923, battling dysentery, in a general ward of a charitable hospital at Ribandar where he had been admitted as an indigent. A life dedicated to the selfless service of the poor and downtrodden had earned for Padre Alvares the admiration of some of his fellow Goans who formed a citizens' committee under the leadership of the Chief Justice, António de Noronha, to take care of the funeral arrangements. The local newspapers carried obit articles recalling the social work of Padre Alvares. His body was kept in state at the municipal hall for twenty-four hours to enable the public to pay their last respects and the funeral procession was taken through the streets of Panjim.

However, since he was a loyal Syrian Orthodox Christian till his last breath, Alvares Mar Julius was buried in a secluded part of the cemetery at Santa Inês, Panjim, amidst great controversy, deprived of a funeral befitting an archbishop. Four years later, on 23 September 1927, his bones were collected by his friends and admirers, placed in a lead box and buried in the same grave with a marble slab that contained the inscription, "Em Memória de Padre António Francisco Xavier Alvares, que foi mui Humanitário Missionario e Um Grande Patriota" (In the memory of Padre António Francisco Xavier Alvares, who was a very Humanitarian Missionary and a Great Patriot). In 
January 1967, the tomb was discovered by the Malankara Orthodox Syrian Church and subsequently, the St. Mary's Orthodox Syrian Church was built at Ribandar where the holy relics were shifted on 5 October 1979. As people believe in the intercession of this apostle of charity, his church in Goa, the St. Mary's Syrian Orthodox Church, was accorded the status of a Pilgrim Centre in September 2008.

The $90^{\text {th }}$ death anniversary of Padre Alvares in September 2013 is an apt occasion to recall his socio-political ideology, especially his determined crusade against corruption and discriminatory practices, his stress on economic self-reliance, and to reiterate the call that he gave to fellow Goans: "Povo de Goa: Surge e Trabalha"25 (People of Goa: Rise and Work)!

"The memory of the righteous is a blessing"

\section{Endnotes}

1 Epitaph inscribed on the tombstone which contains the relics of His Grace Alvares Mar Julius at the Brahmavar church.

2 "The Portuguese connection between Goa and Galle," The Navhind Times (Panaji, Goa), 31 May 2011.

3 Ibid.

4 To quote the Portuguese Captain João Ribeiro, who was in Ceylon from 1640 to 1658 .

5 This is the title of a book written by Fernão de Queiroz, a Jesuit in Goa, in 1688, and published in 1916: Fernão de Queiroz. (1916) Conquista temporal e espiritual de Ceylão, Colombo. This book has been translated into English by S. G. Perera. (1930) The Temporal and Spiritual Conquest of Ceylon, 3 vols., Colombo.

6 I wish to acknowledge, with thanks, the receipt of this chapter by email from Abba Seraphim.

7 The Dogmatic Constitution of the Church Vatican II, Lumen Gentium, 21 November 1964, ch. 1, paragraph 8.

8 By 1543, the Portuguese had annexed the adjoining lands of Bardez in the north and Salcete in the south. These sixteenth century acquisitions of the Portuguese, Ilhas (Tiswadi), Bardez, and Salcete were designated as the 'Old Conquests' ('Velhas Conquistas'). In the second half of the eighteenth century the Portuguese acquired Ponda, Sanguem, Quepem, Canacona, Pernem, Bicholim, and Sattari which were termed as the 'New Conquests' ('Novas Conquistas'). With these political boundaries, Goa remained under the Portuguese until its Liberation in December, 1961.

9 The limited right of franchise led to the establishment of political parties, bourgeoning of the local press that was often critical of the colonial regime, and, generally, an increased political awareness in the territory. In nineteenth century 
Goa there were continuous attempts on the part of the Government to browbeat the electorate into voting for the Government-backed candidate. This resulted in clashes in which innocent people lost their lives. The popular protests against such incidents were articulated through the pen of the journalist, the speeches of the politician and the lyrics of the poet.

10 The term, brahmanism, is derived from the writings of Francisco Luís Gomes, the Goan deputado (Member of Portuguese Parliament) who earned the respect of many in Goa and Portugal by the power of his oratory, the depth of his scholarship and the concern for improving the lot of his people. In his novel, Os Brahmanes, Gomes presents a critique of exploitation ("brahmanism") of all sorts and in all forms, racist, imperialist, casteist, cultural, linguistic and related to gender; and in his A Liberdade de Terra e a Economia Rural da Índia Portuguesa, an economic analysis of the Estado da Índia. Although proud of his Indian heritage, Gomes admitted that Goa could relinquish its colonial ties with Portugal only when its people were united and economically self-sufficient. Vide, The Selected Works of Dr. Francisco Luis Gomes Memorial Volume (Bombay: The Centenary Committee, 1931). Deepa Kolwalkar, Francisco Luis Gomes: His Contribution to the Growth of Political Consciousness in Goa, M. A. dissertation, (Goa University, 1991).

11 An administrative division, smaller than a district.

12 Letter of the people of Ilhas, Bardez and Salcete residing in Bombay to the King of Portugal, dated 31 January 1896.

13 Letter of Gomes da Costa dated 30 July 1895.

14 Article 130: to punish those who do not respect the Roman Catholic religion and do not practise it; Article 134: to punish those who pretend to be Roman Catholic; Article 135: to punish those who, being Catholic, denounce being Catholic; and Article 235: to punish those who publicly wear gowns and ensigns without deserving them.

15 On this occasion, the judge, Vieira Lisboa, had stated that Padre Alvares enjoyed the right to use the episcopal habit of the Syrian Church since Portugal did not discriminate against any religion so long as it did not work against the state.

"The Incredible Story of Alvarez Mar Julius of India": http://www. orthodoxchristianity.net/forum/index.php?topic=2765.0; wap2 Also see, "Parumala Seminary \& The Gospel Missions": http://syrianchurch.org/StGG/ the administrator.htm\#Fr. Alwarez of Roman Catholic Church joins the Syrian Orthodox Church of Antioch.

17 Mar or Mor (Maron) is a courtesy title given to the Bishop, that is Metran or Metropolitan, which means a ruling Bishop: vide, Donald Attwater, The Catholic Encyclopaedia Dictionary (Casseli and co., 1949), 320. For a copy of his ordination letter, vide C.C. de Nazareth, (1927) Clero de Goa, Seus Serviços a Religião e na Nação, Nova Goa: Casa Luso Francesa Editora, 13. For the Syriac text, with English translation, of the certificate of episcopal consecration given to Alvares Mar Julius, see: George A. Kiraz, The Credentials of Mar Julius Alvares Bishop of Ceylon, Goa and India excluding Malabar. Hugoye: Journal of Syriac Studies, v. 7, pp. 157-168. 

malankaraorthodoxalmayavedhi.org/Bava/INDEX.HTML

21 The Catholicate of the Malankara Orthodox Syrian Church: http://mosc.in/index. php?option $=$ com_content\&task $=$ view\&id=19\&Itemid $=10$

22 Ibid

23 Moran Mar Baselius Geevarghese I (1870 - 1928)

24 Ibid.

25 On the title page of the pamphlet, Mandioca (Bastora: Tipografia Rangel, 1916) Alvares exhorts "The people of Goa to rise and work" ("Povo de Goa: Surge e Trabalha").

\section{References}

Alexander, Joseph K. H.G. (2005) Alvares Mar Julius [1889-1923]. Those Who Led Us, v. 4 (07). www.lightoflife.com/LOL_Arch_Alvares_Mar Julius.htm

Alvares, Antonio Francisco Xavier. (1883) Directions for the Treatment of Cholera, Nova Goa: Tipography of "Verdade".

Álvares, A.F.X. Julio I. (1886) Prelecção sobre e situação actual no interior e exterior do paiz lide nos Paços da Camara Municipal das Ilhas aos 22 de Agosto da 1886, Nova Goa: Tipographia do "Times of Goa".

Álvares, A. F. X. Julio I. (1916) Mandioca, Bastora: Tipografia Rangel.

Alvares Mar Julius Metropolitan: http:/www.stalvares.in/

Anson, Peter F. (1964) Bishops at Large, London: Faber \& Faber Limited.

Azevedo, Carmo. (1988) Patriot and Saint The Life Story of Father Alvares/ Bishop Mar Julius I, Panjim.

Boxer, C.R. (1969) The Portuguese Seaborne Empire, 1415-1825, London: Hutchinson and Co.

Brado Indiano, 12 October 1895.

Brandreth, Henry R.T. (2006) Episcopi Vagantes and the Anglican Church, Apocryphile Press. 
Bruto da Costa, Roberto. (1920) A Hidra do Nativismo, Nova Goa: Tipografia Bragança e cia.

The Catholicate of the Malankara Orthodox Syrian Church. http://mosc.in/ index.php?option $=$ com_content $\&$ task $=$ view\&id=19\&Itemid $=10$

Catholicate History. O.S.S.A.E. Publication, Chapter 5. http://www. stgregorioschurchdc.org/cgi/xpage.cgi?doc=ChurchHistory4.lesson

Ciniraj, Paul. Archbishop Alvares Mar Julius (1836-1923). http://www. malankaraorthodoxtv.in/alvaresmarjulius/Archbishop $\% 20$ Alvares $\% 20$ Mar\%20Julius.pdf

Coelho, Sertório. (1895)Uma Página Negra dos Annaes da História Colonial Portugueza, Nova Goa: Tipografia Hitachintak.

Correio da India, 31 August 1895.

da Cunha, António Maria. (1923) A Evolução do Jornalismo, v. I, Nova Goa: Imprensa Nacional.

de Nazareth, C.C. (1927) Clero de Goa, Seus Serviços a Religião e na Nação, Nova Goa: Casa Luso Francesa Editora.

de Queiroz, Fernão. (1916) Conquista temporal e espiritual de Ceylão, Colombo.

de Souza, Caetano Francisco. (1880) Instituições Portuguesas de Educação no Oriente, v. 1, Bombay: Job Printing Press.

de Souza, Teotonio R. (2010) 'Amoras and Amores: The Ambiguities of Colonial Manhandling in Sri Lanka under the Portuguese' in The Portuguese in the Orient, Perera, C. Gaston (ed.), ICES Publication, 239 - 249.

Eglise Gnostique Apostolique and Phillip A. Garver, trans., Les Feuillets D’Hermopolis V Monsignor Joseph René Vilatte Paris 1924-1929, April 2002. www.gnostique.net/documents/vilatte2.pdf

Encylopedia of Western Colonialism since 1450 (=EWC), 2006: 23.

Gomes, Francisco Luis. (1929) Obras Completas III A Liberadade de Terra e a Economia Rural da Índia Portuguesa. Nova Goa: A Livraria Académica.

Hull, E.R. (1927) Bombay Mission History, with a special study of the Padroado Question, v. 1, Bombay: Examiner Press.

Humbert, J. (1964) Catholic Bombay, Her Priests and their Training, 18001928, pt. ii., Bombay: International Eucharistic Congress.

Indian Malankara Orthodox blog: http://vishal-indianmalankaraorthodox. blogspot.in/2009_03_01_archive.html 
A India Portugueza, Margão, 31 August 1895.

Kamat, Pratima. (1989) Popular Reaction to the Religious Policy of the Portuguese in Goa: The Case of Kunkolle. Journal of Indian History, v. LXVII (1-3), pp. 83-90.

Kamat, Pratima. (1999a) Farar Far- Local Resistance to Colonial Hegemony in Portuguese Goa, 1510-1961, Panaji: Institute Menezes Braganza.

Kamat, Pratima. (1999b) Mutiny in the Portuguese Indian Army. GovapuriThe Bulletin of the Institute Menezes Braganza, pp. 69-102.

Kamat, Pratima. (2012) The Indian Cry” (O Brado Indiano) of Padre António Alvares: 'Swadeshi' or 'Seditious'? Indian Church History Review, v. XLVI (1) pp. 69-91.

Keizer, Lewis. (2001) The Wandering Bishops: Apostles of a New Spirituality, $2^{\text {nd }}$ edition, Home Temple Press. http://www.hometemple. org/WanBishWeb\%20Complete.pdf

Kiraz, George A. The Credentials of Mar Julius Alvares Bishop of Ceylon, Goa and India excluding Malabar. Hugoye: Journal of Syriac Studies, v. 7, pp. 157-168.

Luso Goense, Um. (1896) Veredictum da opinião Pública sobre os ‘ Apontamentos para a História da Revolta em Goa dos soldados, Rannes e Satarienses em o anno de 1895' do Sr.Ignacio Caetano de Carvalho, Visconde de Bardez, N.p.

Moran Mar Baselius Geevarghese I (1870 - 1928). http://www. malankaraorthodoxalmayavedhi.org/Bava/INDEX.HTML

Perera, S. G. (1930) The Temporal and Spiritual Conquest of Ceylon, 3 vols., Colombo.

Poothicote, Cherian George. (1990) The Twentieth Century Schism in the Malankara Church. Excelsior, pp. 43-58. http://www.syrianchurch.org/ Articles/PoothicoteZach.htm

The Portuguese connection between Goa and Galle. The Navhind Times (Panaji, Goa), May 31, 2011.

Queen, Andre J. (2005) Credo: The Catechism of the Old Catholic Church. Old Catholic Church of the United States.

Saint Mar Gregorios of Parumala. http://www.thesaintofparumala.com/ history_3.htm

Seraphim, Abba. (2006) Flesh of our Brethren. An historical examination of Western episcopal successions originating from the Syrian Orthodox Patriarchate of Antioch, London: The British Orthodox Press. 
Ultramar, 31 August 1895.

Varghese, Subin. (2009) Holy Brahmavar. theorthodoxchurch.info/blog/ articles/2009/12/holy-brahmavar/

Varghese, Subin. (2010) Holy Brahmavar. The Glastonbury Review, Issue 119. http://britishorthodox.org/glastonburyreview/issue-119-holy-brahmavar/

Vaz, Francisco Xavier and Plácido da Costa Campos, eds. (1925) Monimemta Goana Eclesiástica, v. III, Nova Goa: Tipografia Bragança e Cia.

Vinte e um de Setembro, 24 August 1895.

Weeks, Donald Pierce. Joseph René Vilatte. First Independent Catholic Prelate in North America, Parts 1-12. http://www.concentric.net/ cosmas/vilatte. htm

Županov, Ines G. (2006) 'Goan Brahmans in the Land of Promise: Missionaries, Spies and Gentiles in Seventeenth and Eighteenth Century Sri Lanka' in Re-exploring the Links History and Constructed Histories between Portugal and Sri Lanka, Flores, Jorge (ed.), Wiesbaden: Harrassowitz Verlag and the Calouste Gulbenkian Foundation, 171-210. 